\title{
Health Promoting School Program to Prevent Hypertension of Adolescents in Indonesia and Western
}

\author{
Maninggar Kayuningtyas ${ }^{1)}$, Ismayani ${ }^{2)}$ \\ 1 Department of Health Promotion and Behavior Science, Faculty of Public Health, Universitas \\ Airlangga, Surabaya, Indonesia \\ 2 Provincial Health Office, East Java, Indonesia \\ Email: maninggar.kayuningtyas-2017@fkm.unair.ac.id
}

\begin{abstract}
Background: Complications of hypertension causes 9.4 million of death worldwide each year. The risk factors for hypertension include heredity and environmental factors such as obesity, salt intake, physical activity, and alcohol. One-third of teenagers spent their time on school activities, so schools contribute to preventing hypertension in adolescents through Health School Program activities. Objective: to compare the health-promoting school program in Indonesia and Western in the prevention of hypertension. Method: The method used in writing this article was a literature review from 11 specific articles that were collected through google scholar, ProQuest, and SAGE pub search engines, with article inclusion criteria published in 2013-2019, keyword hypertension, adolecent, health school, programs. The spesific criteria of the article based on the aspect of healthpromoting school programs such as policy, supportive environment, the role of teachers and parents, and stakeholder. The country in the article in Indonesia and western Result: the review found that health promotion program in schools which was implemented in Indonesia has not been effective in preventing the emergence of risk factors for the incidence of hypertension in adolescents, compared with implementation in western. Ineffectiveness that occurs due to nutritional control patterns in adolescents in schools in the absence of regulations governing the nutritional content of student food, the lack of the teacher's role in implementing health education due to high academic demands, and the lack of parental involvement. Conclusion: There are differences in the implementation of the health promotion program in Indonesia and the Western. The government priority for increasing the quality of live students trough health-promoting schools.
\end{abstract}

Keywords: Adolescence, Hypertension, Health Promoting School Program

\section{INTRODUCTION}

Cardiovascular disease causes 17 million death every year or nearly onethird of the total in Global. In comparison, hypertension complications cause 9.4 million death worldwide each year. Hypertension has a role in $45 \%$ of deaths due to heart disease, and $51 \%$ of deaths due to stroke (World Health Organization, 2013). Increased risk of early childhood death in most countries is due to Non-Communicable Diseases (NCD), damage, and mental health. All these are three priorities in global child health. Nearly 1.2 millions adolescent die in 2015 , or more than 3000 every day, most of which are caused by diseases that can be prevented or treated (World Health Organization, 2015).
Hypertension is an increase in systolic blood pressure $>140 \mathrm{mmHg}$ and diastolic blood pressure $>90 \mathrm{mmHg}$ at two blood pressure measurements taken within 5 minutes in a calm and reasonably good condition (Reboussin et al., 2018; Kementerian Kesehatan Republik Indonesia, 2019). The prevalence of hypertension in Indonesia has decreased from $31.7 \%$ in 2007 to $25.8 \%$ in 2013 . The incidence of hypertension has increased from 2018 to 34.11\% (Kementerian Kesehatan Republik Indonesia, 2019). However, the prevalence of hypertension in adolescents (14-17 years) in Indonesia was only recorded in the Basic Health Research or Riset Kesehatan Dasar (RISKESDAS) 2013 at 5.3\% (Kementerian Kesehatan Republik Indonesia, 2013). 
Hypertension generally occurs in an adult. Nevertheless, in the globalization era, all become instantaneous that resulting in an increasingly early age of hypertension. Several previous studies have shown that hypertension can occur since adolescence, and this case is increasing from year to year. Another research shows that as many as $12 \%$ of Hidayatul Islamic High School students in Semarang City suffer from hypertension (Kurnianingtyas, Suyatno and Kartasurya, 2017). In Depok City, there are 44.2\% or 61 out of 144 students in high school had hypertension at the 95th percentile (Angesti, Triyanti and Sartika, 2018).

The risk factors for hypertension include heredity and environmental factors such as obesity, salt intake, physical activity, and alcohol. It is consistent with the statement from the American Heart Association that there are environmental factors that influence the occurrence of hypertension, such as salt intake, physical activity, alcohol, and smoking habits (Reboussin et al., 2018). Similar to adolescents at this time, factors that cause hypertension in adolescents that can be changed are from the environment, from food consumption patterns, including fiber intake and nutrition as well as physical activity patterns in adolescents to avoid the occurrence of adolescent hypertension (Spagnolo et al., 2013; Lisiswanti and Dananda, 2016; Supiati, Ismail and Siwi P, 2016; Kurnianingtyas, Suyatno and Kartasurya, 2017; Angesti, Triyanti and Sartika, 2018).

Health Promoting School (HPS) is the school that continually seeks to strengthen its capacity to promote healthy living, learning, and working conditions. It aims to provide a multifaceted response to the health needs of students (World Health Organization, 2017). Health promotion in schools is an effective and efficient way to reach large numbers of people. In 2018, over $90 \%$ of children of primary school age and over $80 \%$ of children of lower secondary school age were enrolled in school globally (United Nations Children's Fund, 2018). In Indonesia, the number of students from elementary to high school in the age range of 5-19 years is around 44,308,247. Youth activities with an age range of 1417 years, one third spent on school activities. By promoting health behavior and through school settings, enhancing the lives of other family members and community, schools can also directly reach out to family members and the community.

In Indonesia, Constitution Law Number 36 of 2009 concerning Health, article 79, which reads, "School health is held to improve the ability to live healthy learners in a healthy environment so that students can learn, grow, and develop harmoniously and become qualified human resources. "The School Health Program or Unit Kesehatan Sekolah (UKS) work program includes three elements, namely health education in schools, health services in schools, and fostering a healthy school environment that is embodied in the "Trias UKS" (UndangUndang Republik Indonesia Nomor 36 Tahun 2009 tentang Kesehatan, 2009). However, this program has not been effective in Indonesia. In high-income countries, school settings represent an extended arm of primary health care by providing essential health care services.

Behaviors and habits develop in early childhood children acquire basic knowledge and experiences that influence their lifestyles in adulthood. Such as in America has implemented a Health School program. This program explained that there were eight components discussed in the "Health School Program" at ASHA (American School Health Association), such as school environment, health education, health services, physical education, counseling, guidance, and health mental health, nutrition, and food, health promotion and school integration and community health activities. Meanwhile in the UK adopted the HPS framework from WHO, and in Brazil adheres to the National Political Health Promotion (PNPS) program that began in 2006, focusing on strengthening across, integrated and intersectoral policy, which promotes dialogue between various departments with society as well, forming networks of commitment and responsibility in formulating proposals and actions to ensure the quality of life of the population (Macuch et al., 2015).

Health promotion in schools has a role in overcoming hypertension. Health promotion programs in Indonesia have not been fully implemented, while in some western countries such as Brazil, the UK, 
and the USA, health promotion programs have succeeded in the risk factor for hypertension. The success of health promotion abroad was questioned by several factors, as seen by parents, the existence of a good education curriculum, appropriate nutrition fulfillment program, and strong cross-sectoral cooperation established (Nihiser, Merlo and Lee, 2015; Bezerra et al., 2018). Based on that explanation, it is necessary to compare it with the health-promoting program in Indonesia and the Western.

\section{METHOD}

The method used in writing this article is a literature review from the Google Scholar search engine, SAGE pub, and ProQuest. The literature search found 50 related articles based on risk factors of hypertension in adolescent and Health Promoting Schoolsand hypertension in adolescents and years that the article published between 2013-2019. Totaly articles was 1.324 with keyword adolecent hypertension. After that the reseacher adding keyword by health promoting, school, program. Just 11 articles was related and relevant. The criteria of the article based on the aspect of health-promoting school programs such as policy, supportive environment, the role of teachers and parents, and stakeholders. After reading the articles, 11 articles met the criteria for further review in the journal. The articles was implement health school program about adolecent hypertension in Indonesia and western. It is to compare the implemented of programs.

\section{RESULTS AND DISCUSSION}

The literature review results show that each HPS program in each region has the same scheme, which is a policy, a supportive school environment, the role of the teacher, and the support of parents and related stakeholders.

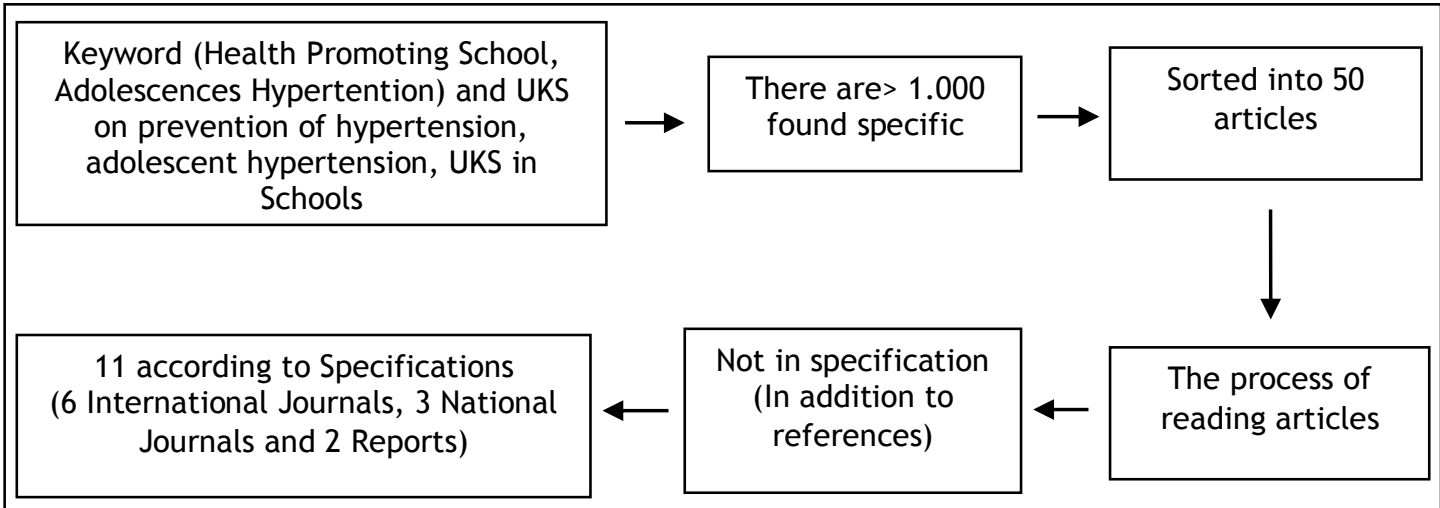

Figure 1. Scheme of Literature review

The Role of the UKS in Reducing Hypertension in Indonesia

The UKS in Indonesia is protected by Law Number 20 of 2003 concerning the National Education System and Law Number 36 of 2009 article 79. The purpose of the national education system is to educate the life of the nation and develop the Indonesian people as a whole, that is, as humans who have faith and devotion to God Almighty and virtuous character, have knowledge and skills, physical and spiritual health, a solid personality and independence and sense of community and national responsibility. In order to achieve the objectives, especially physical health and knowledge, Law Number 36 of 2009 about Health article 79 states that School Health is held to improve the ability to live healthy learners in a healthy environment so that students learn, grow and develop harmoniously and as high as possible to become qualified human resources (Undang-Undang Republik Indonesia Nomor 20 Tahun 2003 tentang Sistem Pendidikan Nasional, 2003; UndangUndang Republik Indonesia Nomor 36 Tahun 2009 tentang Kesehatan, 2009).

The UKS Program is one of the youth health program efforts that involve multi-sectors (education, religion, health, and social sectors). However, not all of them are actively involved, especially in developing youth health promotion media (Muthmainnah et al., 2020). Efforts to 
promote the healthy school in preventing diseases are included in the three elements of the UKS program, called "Trias UKS". There are health education, health services, and fostering a healthy school environment. Each component has its contents to achieve a healthy school following the law. This program shows that the efforts to implement UKS in many schools were reasonable, but the implementation of this program is not yet fully distributed throughout the region. Also, there is no particular UKS program in preventing hypertension.

At the level of health services in schools in handling risk factors for the incidence of hypertension in students at school is not optimal. UKS has been implemented, but its performance has not been on efforts to prevent hypertension. One risk factor for hypertension is obesity. Many schools do not have programs for tackling obesity in schools because the number of students who are obese is small (Fridayanti and Prameswari, 2016). Efforts to service activities in schools carried out by teachers only measure the weight and height of students, without classifying nutritional status (Nugraheni, Prayoga and Aida, 2019).

Health service in school as one of the elements of UKS has not been utilized to the maximum by students. Students have not maximally utilized UKS as an effort to prevent obesity as a risk factor for hypertension. Students only use UKS if they feel unwell. Efforts to consult with UKS coaches about hypertension risk factors have also not been carried out. So the level of student knowledge is still low (Fridayanti and Prameswari, 2016). In general, UKS coaches are physical education teachers. Teachers are very instrumental in efforts to promote health in schools, in efforts to prevent risk factors for hypertension. Good teacher knowledge and attitude about prevention efforts will affect the implementation of health promotion efforts and increase teacher motivation in examining students' BMI regularly and continuously in the prevention of obesity as a risk factor for hypertension (Nugraheni, Prayoga and Aida, 2019)

UKS also has not carried out its role optimally due to a lack of health training. Health education regarding risk factors for hypertension has also not been conveyed in full. In the guideline for implementing UKS in schools, health education materials delivered related to risk factors for hypertension are the dangers of cigarette and liquor consumption (Elementary school), patterns, and concepts of healthy and nutritious food (Junior high school). While at the high school level, health education does not cover at all the efforts to prevent hypertension risk factors and emphasizes the analysis of the dangers of drugs and free sex.

Another part that should be considered by the state in implementing health promotion in schools in efforts to prevent hypertension in adolescents is the quality of human resources they have. UKS Teachers and Trustees play an essential role in health education efforts in schools. The coach of UKS itself is a teacher who is appointed and trained by the community health care to help disseminate information and provide health education at the school. At present, there are still many teachers who do not receive training on health education because of the lack of equal training provided by community health care, which is likely due to the change of teachers in schools and training schedules that are not routinely conducted (Nugraheni, Prayoga and Aida, 2019). Also, the material provided during the training was not specific to the prevention of hypertension (Fridayanti and Prameswari, 2016).

At present, there is no educational curriculum in Indonesia, specifically aimed at the prevention of specific diseases. Health learning materials available in schools are only general in common. At present, the school curriculum is divided into two; it is an intraculicular and extracurricular curriculum. Extracurricular activities are more focused on students' abilities, especially in the areas of physical activity and the arts (Irnanda, 2017).

The third part of Trias UKS is a healthy development environment. The development of a healthy environment in schools aims to create a healthy environment in schools that allows school residents to achieve the highest degree of health. Efforts to establish a healthy environment in schools as an effort to prevent hypertension are not smoking and drinking alcohol. All schools have 
implemented a ban on smoking and drinking in the school environment. Also, in this effort, all schools have established healthy canteens within the school environment. However, the canteen only complies with National Agency of Drug and Food Control or Badan Pengawas Obat dan Makanan (BPOM) regulations regarding food that is suitable for consumption but does not pay attention to the nutrition in the food being sold.

Efforts to create a fostering and healthy school environment concerning the prevention of hypertension in adolescents in Indonesia have not yet been fully achieved. A healthy school environment includes the role of all school members, including students, educators, education staff, and the school community (Irwandi, Ufatin and Sultoni, 2016). Currently, according to the 2015 GSHS (Global School Health Survey) survey of school children from elementary through high school, shows that the main risk factors for health problems are the lack of consumption of vegetables and fruits. Meanwhile, Food Safety Guidelines in Elementary School (2011) and the School Canteen Food Safety Charter (2012) only discuss food safety standards that must be provided in schools, ranging from handling, storage, processing, and presentation, must be following hygiene standards and sanitation of food and food provided must have obtained permission from BPOM. The two guidelines do not explain the nutritional value of food that should be provided in schools. When we refer to the UKS program, it only fits that the school canteen not only sells safe food but must be able to meet the daily nutritional needs of school children.

Patterns of consumption of unhealthy foods, such as too much salt, excessive carbohydrates, and fast food, trigger obesity. Obesity is one of the risk factors for hypertension (Syafni and Wijayanti, 2015; Lisiswanti and Dananda, 2016; Tarigan, Lubis and Syarifah, 2018). The Indonesian Ministry of Health in 2012 made guidelines on the Prevention and Management of Overweight and Obesity in School Children. This guideline was made as an early effort to prevent obesity in childhood because obesity in childhood is at high risk of becoming obese in adulthood and has the potential to experience metabolic and degenerative diseases in the future (Kementerian Kesehatan Republik Indonesia, 2012).

Factors in hypertension other than eating patterns are decreased physical activity and increased sedentary lifestyle (Spagnolo et al., 2013; Pramudita and Nadhiroh, 2017). Low physical activity increases the risk of hypertension compared to someone with sufficient activity (Farabi et al., 2015; Ewald and Haldeman, 2016). Obesity is not only related to how much to consume food but also because of a lack of physical activity (Ramadhani and Sulistyorini, 2018). A person who is obese is known to have a potential 1.68 times to suffer from hypertension (Dhika Rohkuswara and Syarif, 2017). The other researchers also found that the majority of obese sufferers in adolescents in Jakarta also experience hypertension (Pramudita and Nadhiroh, 2017).

Program to fulfill nutrition in adolescents should be encouraged by the government, such as the existence of regulations regarding restrictions on food standards that should be circulated in schools. Currently, the nutrition fulfillment program through the Progam (School Children Nutrition Program) is still focused on the nutrition of children in Primary Schools (Santoso et al., 2017). Fulfillment of daily nutrition of adolescents is the following guidelines for the prevention and control of obesity and obesity in school children, where obesity is a risk factor for hypertension. As for the lifestyle that is expected to prevent risk factors for hypertension are:

- Consumption of fruits and vegetables = five servings per day

- Puts limits on watching TV, playing computer, game/playstation <2 hours/day

- Does not provide TV in a child's room

- $\quad$ Reducing sweet foods and drinks

- Reducing fatty and fried foods

- Reducing outside food consumption

- Making a habit of having breakfast and bringing lunch to school

- Familiarizing eating with family at least once a day

- Eat according to time

- Increase physical activity at least 1 hour/day

Involve families for lifestyle improvement to prevent overnutrition 
Factors in hypertension other than eating patterns are decreased physical activity and increased sedentary lifestyle (Spagnolo et al., 2013; Pramudita and Nadhiroh, 2017). Low physical activity increases the risk of hypertension compared to someone with sufficient activity (Farabi et al., 2015; Ewald and Haldeman, 2016). Obesity is not only related to how much to consume food but also because of a lack of physical activity (Ramadhani and Sulistyorini, 2018). A person who is obese is known to have a potential 1.68 times to suffer from hypertension (Dhika Rohkuswara and Syarif, 2017). The other researchers also found that the majority of obese sufferers in adolescents in Jakarta also experience hypertension (Pramudita and Nadhiroh, 2017).

Physical activities have not been discussed explicitly in the UKS Program. Lack of physical activity is one of the risk factors for the incidence of hypertension in adolescents. Guidelines for obesity prevention explain that it should be carried out 3-4 hours a week. The research found that $57,3 \%$ of Indonesian children were categorized as not actively doing activities (Harahap, Sandjaja and Cahyo, 2013). Adolescents with more nutrition have a sedentary activity of $>8$ hours/day (Pramudita and Nadhiroh, 2017).

Tabel 1. Discussion Topics for Health Promoting School

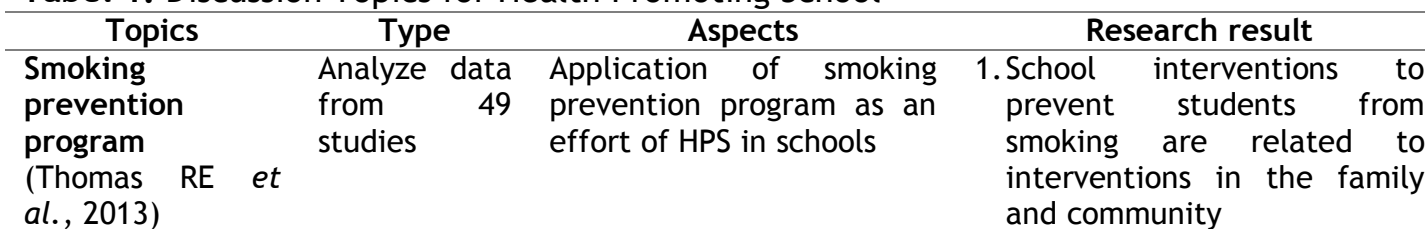

2. Support from the school environment and school friends influence the prevention of smoking in adolescents

School health Qualitative HPS Regulations and It has been prepared by the
program in Brazil Study Policies relevant ministries to improve (Macuch, 2015) the quality of life of students, but the budget still constrains it.

\begin{tabular}{|c|c|c|c|}
\hline $\begin{array}{l}\text { Health } \\
\text { Promoting } \\
\text { Schools in Brazil } \\
\text { (Bezerra et al., }\end{array}$ & $\begin{array}{l}\text { Cross- } \\
\text { sectional } \\
\text { study }\end{array}$ & $\begin{array}{l}\text { Participation in the school } \\
\text { environment community, } \\
\text { creating } \\
\text { environmental conditions, }\end{array}$ & $\begin{array}{l}\text { Not effective yet, efforts } \\
\text { explain school nutrition polic } \\
\text { have not been sufficient } \\
\text { improve students' health stat }\end{array}$ \\
\hline
\end{tabular}
2018) school nutrition policy, Monitoring the nutritional status and cross-sectoral cooperation

\begin{tabular}{|c|c|c|}
\hline Health Promoting & Literature & Nutrition policy at school, \\
\hline $\begin{array}{l}\text { School in the } \\
\text { USA }\end{array}$ & Review & $\begin{array}{llr}\text { physical } & \text { activity } & \text { policy, } \\
\text { and } & \text { system } & \text { and }\end{array}$ \\
\hline
\end{tabular}
(2015)

$\begin{array}{ll}\text { Health Promoting } & \text { Qualitative } \\ \text { School in the UK } & \text { research on } \\ \text { (Clarke et al., } 22 \text { principals } \\ \text { 2015) }\end{array}$

Curriculum, extracurricular, healthy school policy, nutrition in school, cross-sectoral cooperation, cooperation with parents, role models, and external factors

$\begin{array}{lll}\text { Health } & \text { Literature } & \text { Curriculum, environment, } \\ \text { Promoting School review } & \text { and family / Community } \\ \text { (All around the } & & \\ \text { world) } & \end{array}$

Policies that have been formed will be achieved by building strong relationships between educational organizations and the surrounding environment (parents, community, and stakeholders)

1. Healthy school policies that demand the role of teachers, experience obstacles because of the heavy tasks of the teacher and the demands of high student achievement

2. Parental support enhances program success

1. A good curriculum will support the Health Promotion Program for the behavior change process 
234 Jurnal Promkes: The Indonesian Journal of Health Promotion and Health Education Vol. 8 No. 2, September 2020, 228-237 doi: 10.20473/jpk.V8.12.2020.228-237

\begin{tabular}{lll}
\hline \multicolumn{1}{c}{ Topics } & \multicolumn{1}{c}{ Type } & \multicolumn{1}{c}{ Aspects } \\
\hline $\begin{array}{ll}\text { (Langford et al., } \\
\text { 2015) }\end{array}$ & \\
& & \\
\hline $\begin{array}{l}\text { UKS in Semarang } \\
\text { (Devinta, 2016) }\end{array}$ & $\begin{array}{l}\text { Qualitative } \\
\text { Study }\end{array}$ & $\begin{array}{l}\text { Facilities, management } \\
\text { UKS, and action in trias } \\
\text { UKS }\end{array}$
\end{tabular}
UKS
2. 4. Environmental and family
support increases the
success rate of HPS

1. There is no priority program to prevent obesity

2. They have not yet reported the results of weighing $B B$ and TB and blood pressure.

3. Food provided by schools has not yet focused on the value of the nutritional status

\begin{tabular}{|c|c|c|c|}
\hline $\begin{array}{l}\text { UKS in Mataram } \\
\text { (Irwandi, 2016) }\end{array}$ & $\begin{array}{l}\text { Qualitative } \\
\text { Study }\end{array}$ & Teacher's role & $\begin{array}{l}\text { The role of good teachers and } \\
\text { principals will accelerate } \\
\text { changes in health behavior. } \\
\text { (Although in this case it is not } \\
\text { discussed regarding } \\
\text { hypertension) }\end{array}$ \\
\hline
\end{tabular}

UKS in Semarang Crossectional Teacher's role

(Nugraheni, 2019)

1. Good knowledge of UKS teachers will increase the activeness and attitude of teachers in health promotion

2. Unequal provision of training for teachers on health education

\begin{tabular}{|c|c|c|c|}
\hline $\begin{array}{l}\text { Report on the } \\
\text { Application of } \\
\text { HPS in the USA } \\
\text { (Winterfeld, } \\
\text { 2014) }\end{array}$ & eport & $\begin{array}{l}\text { Application of HPS in all } \\
\text { parts of the USA }\end{array}$ & $\begin{array}{l}\text { Each region has its regulations } \\
\text { and policies. } \\
\text { One thing that needs to be } \\
\text { emulated is the effort to create } \\
\text { healthy food by growing } \\
\text { vegetables at school. }\end{array}$ \\
\hline $\begin{array}{l}\text { Policy report } \\
\text { School food and } \\
\text { Nutrition in } \\
\text { Europe } \\
\text { (Storcksdieck et } \\
\text { al., 2014) }\end{array}$ & Report & $\begin{array}{l}\text { Strategy to reduce the } \\
\text { number of overweight, } \\
\text { Increased consumption of } \\
\text { vegetables in families with } \\
\text { income }<50 \% \text { on average in } \\
\text { the European Union and } \\
\text { promoting a healthy diet in } \\
\text { adolescents to prevent } \\
\text { cardiovascular disorders }\end{array}$ & $\begin{array}{l}\text { 1. Increasing school } \\
\text { collaboration with } \\
\text { stakeholders } \\
\text { 2. Nutrition education in the } \\
\text { curriculum } \\
\text { 3. Increased physical activity } \\
\text { regulated in the curriculum } \\
\text { 4. Collaboration with parents } \\
\text { of students }\end{array}$ \\
\hline
\end{tabular}

The Success of the Health Promoting School in the World

The Centers for Disease Control and Prevention (CDC) Department of Health and Human Services formulates ten steps of school-based prevention strategies that must be applied by a country. Those steps are:

- Coordinating and integrating programs related to school health in all institutional states and with nongovernmental organizations;

- Use state and local data to guide decision making, and policy formulation;

- Support the development of school health councils and strengthen health planning in schools;

- Establish strong health policies;
- Increase the capacity of school staff through certification and professional development;

- Establish a time for physical activities;

- Establish nutritional standards for food and drinks offered at school;

- Promote high-quality health education and physical education;

- Support student participation in high-quality school food programs;

- Supporting opportunities for students to engage in physical activity;

- Consume healthy food.

The success of European countries in conducting Health Promoting School efforts in schools to prevent the emergence of hypertension is not only from handling food but also regulating the consumption of food consumed in schools, 
starting from breakfast and lunch. One example is the SHE program (School for Health in Europe) developed in EU countries, covering 28 countries, including Norway and Switzerland. This program not only discusses how to handle and process food, but also includes the fulfillment of nutrition for teenagers in school. Food and nutrition standards are regulated in this program, including the availability of drinking water, fruit and vegetables in schools, and the prohibition of soft drinks, snacks, and fast food (Storcksdieck et al., 2014).

Likewise, the program implemented in America, in addition to maintaining the nutrition intake of adolescents in schools through the provision of healthy and nutritious food in the canteen, also implements the existence of a school garden (Farm to School). Nine states have implemented this program in America. Farm to School's efforts are not only expected to bring healthy and fresh food to the canteen, but it can also be used as a new nutritional standard. The purpose of this activity is expected to increase students' knowledge about nutrition and agriculture, as well as to help improve the economy by growing markets in schools (Winterfeld, 2014). Health promotion efforts in schools (Health Promoting School) in several developed countries have shown its benefits for adolescents in reducing risk factors from the incidence of noncommunicable diseases, one of which is hypertension. The efforts taken are to increase physical activity, reduce cigarette use, and increase the consumption of fruits and vegetables (Roger E. Thomas, R and Perera, 2013).

The scope of the application of Health Promoting School in developed countries does not only involve teachers and students. However, it also involving family involvement. Such as giving magazines and announcements for physical activity (UK) and the application of activity card reports, and the presence of student guardian (USA) meetings. These health promotion efforts have proven to be effective in increasing physical activity and fulfilling nutrition in adolescents (Langford et al., 2015).

Also, awareness from school administrators is essential. Awareness and support from schools such as teachers and school principals will support the success of existing health promotion programs. In, a study conducted the UK, explained that of the 22 principals interviewed for health promotion programs, all of them were already aware of the importance of schools in the successful efforts to tackle hypertension risk factors. So there are various extracurricular activities such as cooking so that students can cook healthy food. However, there are still various obstacles encountered, namely government regulations that do not support and the low level of support from families, which is only around $17 \%$. Although there is still a little role of the family, the family feels that there is a health promotion program in schools by distributing brochures, holding meetings, and providing health education is considered beneficial because it can increase the concentration of learning in students (Clarke et al., 2015)

Efforts for the success of the Health Promoting School are based entirely on cross-sectoral cooperation between related agencies. In Brazil, efforts to implement HPS are based on the Ministry of Health and the Ministry of Education. The obstacle to implementing HPS is finance, and the process of implementing it is complicated (Macuch et al., 2015). Building strong collaboration between the health department and the education office will be able to form new programs that are more sustainable and sustainable so that teachers owned by schools can develop and have more specialized knowledge on hypertension prevention strategies (Nihiser, Merlo and Lee, 2015).

\section{CONCLUSION}

There are differences in the application of health promotion in the prevention of hypertension in Indonesia and Western. The success of health promotion in western due to the involvement of parents and the implementation of a consistent program. Efforts to promote school health regarding hypertension in Indonesia have not been fully implemented well. There were still many things that need to be addressed in implementing health promotion in schools that are in the UKS program. One of them is food control, as the intake of nutrients circulating at school. Also, increasing the 
role of staff and teachers in schools also needs to be improved.

Health Promoting Schools in Indonesia need to be improved to improve the quality of life of students. The government's priority in the prevention of hypertension, and the need for policies on food nutrition that are allowed to circulate in schools, as well as increasing parental participation in helping the success of health promotion programs.

\section{REFERENCE}

Angesti, A. N., Triyanti, T. and Sartika, R. A. D. (2018) 'Riwayat Hipertensi Keluarga Sebagai Faktor Dominan Hipertensi pada Remaja Kelas XI SMA Sejahtera 1 Depok Tahun 2017', Buletin Penelitian Kesehatan, 46(1), pp. 1-10. doi: 10.22435/bpk.v46i1.41.

Bezerra, D. A. et al. (2018) 'Health promotion initiatives at school related to overweight, insulin resistance, hypertension and dyslipidemia in adolescents: a cross-sectional study in', BMC Public Health. BMC Public Health, 18, pp. 1-12.

Clarke, J. L. et al. (2015) 'Parent and child perceptions of school- based obesity prevention in England: a qualitative study', BMC Public Health. BMC Public Health, pp. 1-9. doi: 10.1186/s12889-015-2567-7.

Dhika Rohkuswara, T. and Syarif, S. P. (2017) 'The Relationship of Obesity with Incidence of Hypertension Stage 1 at Integrated Coaching Post of NonCommunicable Disease (Posbindu PTM) Port Health Off ice of Bandung in 2016', Jurnal Epidemiologi Kesehatan Indonesia, 1(2), pp. 13-18.

Ewald, D. R. and Haldeman, L. A. (2016) 'Risk Factors in Adolescent Hypertension', Global Pediatric Health, 3, p. 2333794X1562515. doi: $10.1177 / 2333794 \times 15625159$.

Farabi, A. F. et al. (2015) 'Faktor-Faktor Yang Berhubungan Dengan Hipertensi', Jurnal Kesehatan Masyarakat, 7(7), pp. 10-15. doi: 10.1136/pgmj.51.599.683-c.

Fridayanti, D. V. and Prameswari, G. N. (2016) 'Peran UKS dalam Upaya Penanggulangan Obesitas pada Anak Usia Sekolah', Journal of Health Education, 1(2), pp. 56-61. doi: 10.1080/10556699.1992.10616274.

Harahap, H., Sandjaja and Cahyo, K. N.
(2013) 'Pola Aktivitas Fisik Anak Usia 6,0-12,9 Tahun Di Indonesia', Gizi Indonesia, 36(2), pp. 99-108. doi: 10.1017/CBO9781107415324.004.

Irnanda, D. (2017) 'Kebijakan Institusi Pendidikan dalam Pengelolaan Obesitas Siswa', Jom Fk, 4(2), pp. 116.

Kementerian Kesehatan Republik Indonesia (2012) Pedoman Pencegahan Dan Penanggulangan Kegemukan Dan Obesitas pada Anak Sekolah, Kementerian Kesehatan Republik Indonesia.

Kementerian Kesehatan Republik Indonesia (2013) Riset Kesehatan Dasar. Jakarta.

Kementerian Kesehatan Republik Indonesia (2019) Laporan Nasional Riskesdas Tahun 2018. Jakarta.

Kurnianingtyas, B. F., Suyatno and Kartasurya, M. I. (2017) 'Faktor Resiko Kejadian Hipertensi Pada Siswa SMA di Kota Semarang Tahun 2016', Jurnal Kesehatan Mayarakat, 5(2), pp. 408419. doi: $10.20473 /$ jbe.v4i3.

Langford, R. et al. (2015) 'Obesity prevention and the Health promoting Schools framework: essential components and barriers to success', International Journal of Behavioral Nutrition and Physical Activity, 12(15), pp. 3-17. doi: 10.1186/s12966-015-0167-7.

Lisiswanti, R. and Dananda, D. N. A. (2016) 'Upaya Pencegahan Hipertensi', Majority, 5(September), pp. 50-54.

Macuch, R. D. S. et al. (2015) 'School Health Program: A Course Analysis', Saúde e Pesquisa, 8(2), p. 297. doi: 10.17765/1983-1870.2015v8n2p297306.

Muthmainnah et al. (2020) 'Powerattitude-interest of stakeholoders in developing adolescent health promotion media', International Journal of Innovation, Creativity and Change, 11(6), pp. 287-299.

Nihiser, A., Merlo, C. and Lee, S. (2015) 'Preventing Obesity through Schools', J Law Med Ethics, 41(02), pp. 27-34. doi: $10.1111 /$ jlme.12106. Preventing.

Nugraheni, H., Prayoga, A. N. and Aida, W. N. (2019) 'Peran Guru dalam Kegiatan Promosi Kesehatan Pencegahan Obesitas pada Siswa Sekolah Dasar', Jurnal Promosi Kesehatan Indonesia, 14(1), p. 53. 
doi: $10.14710 /$ jpki.14.1.53-67.

Pramudita, S. R. and Nadhiroh, S. R. (2017) 'Gambaran Aktivitas Sedentari Dan Tingkat Kecukupan Gizi Pada Remaja Gizi Lebih Dan Gizi Normal', Media Gizi Indonesia, 12(1), pp. 1-6. doi: $10.20473 /$ mgi.v12i1.80-87.

Ramadhani, E. T. and Sulistyorini, Y. (2018) 'The Relationship between Obesity and Hypertension in East Java Province in 2015-2016', Jurnal Berkala Epidemiologi, 6(1), p. 35. doi: 10.20473/jbe.v6i12018.35-42.

Reboussin, D. M. et al. (2018) 'Systematic Review for the 2017 ACC/AHA/AAPA/ABC/ACPM/AGS/APhA /ASH/ASPC/NMA/PCNA Guideline for the Prevention, Detection, Evaluation, and Management of High Blood Pressure in Adults: A Report of the American College of Cardiology/American Heart Association', Circulation, 138(17), pp. e595-e616. doi: 10.1161/CIR.0000000000000601.

Roger E. Thomas, R, J. M. and Perera, R. (2013) 'School-based programmes for preventing smoking (Cochrane Review)', The Cochrane Library, 4(4). doi:

10.1002/14651858.CD001293.pub3.w ww.cochranelibrary.com.

Santoso, A. et al. (2017) Media Komunikasi dan Inspirasi Jendela Pendidikan dan Kebudayaan. 12th edn. Kementerian Pendidikan dan Kebudayaan.

Spagnolo, A. et al. (2013) 'Focus on prevention, diagnosis and treatment of hypertension in children and adolescents', Italian Journal of Pediatrics. Italian Journal of Pediatrics, 39(1), p. 1. doi: 10.1186/1824-7288-39-20.

Storcksdieck, S. et al. (2014) School Food and Nutrition in Europe: policies, interventions and their impact.

Supiati, S., Ismail, D. and Siwi P, R. (2016) 'Perilaku makan dan kejadian obesitas anak di SD Negeri Kota Kendari, Sulawesi Tenggara', Jurnal
Gizi dan Dietetik Indonesia (Indonesian Journal of Nutrition and Dietetics), 2(2), p. 68 . doi: 10.21927/ijnd.2014.2(2).68-74.

Syafni, A. and Wijayanti, H. S. (2015) 'Hubungan Konsumsi Western Fast Food Dengan Hipertensi Pada Remaja di SMAN 1 Semarang', Journal of Nutrition College, 4(2), pp. 358-364.

Tarigan, A. R., Lubis, Z. and Syarifah (2018) 'Pengaruh Pengetahuan, Sikap Dan Dukungan Keluarga Terhadap Diet Hipertensi Di Desa Hulu Kecamatan Pancur Batu Tahun 2016', Jurnal Kesehatan, 11(1), pp. 9-17. doi: 10.24252/kesehatan.v11i1.5107.

Undang-Undang Republik Indonesia Nomor 20 Tahun 2003 tentang Sistem Pendidikan Nasional (2003). Jakarta.

Undang-Undang Republik Indonesia Nomor 36 Tahun 2009 tentang Kesehatan (2009). Indonesia.

United Nations Children's Fund (2018) Annual Report 2018 For Every Child, Every Right.

Winterfeld, A. (2014) State actions to reduce and prevent childhood obesity in schools and communities: Summary and analysis of trends in legislation.

World Health Organization (2013) A global brief on Hypertension 'Silent killer, global public health crisis', World Health Organization. doi: 10.1136/bmj.1.4815.882-a.

World Health Organization (2015) Global School Health Initiatives: Achieving Health and Education Outcomes REPORT OF A MEETING, Geneva: World Health Organization. Thailand.

World Health Organization (2017) 'HEALTH PROMOTING SCHOOLS- An Effective Approach To Early Action On Noncommunicable Disease Risk Factors', World Health Organization World Health Organization European Journal of Public Health. Cochrane Database Systematic Reviews. Geneva: World Health Organization, 21854(7610), pp. 558-81002. doi: 10.1093/eurpub/ckn061.13. 